\title{
Experimental study of the therapeutic application of oxytetracycline, its attenuation in sediment and sea water, and implications for farm culture of benthic organisms
}

\author{
Hervé Pouliquen ${ }^{1}$, Hervé Le Bris ${ }^{2}$, Louis Pinault ${ }^{1}$ \\ ${ }^{1}$ Service de pharmacie et toxicologie, and ${ }^{2}$ Service d'aquaculture et pathologie aquacole, Ecole Nationale Vétérinaire, \\ CP 3013, F-44087 Nantes, Cedex 03, France
}

\begin{abstract}
A rapid procedure is presented for the quantitative determination of oxytetracycline (OTC) in sediment using high-performance liquid chromatography. The limits of detection and determination were respectively, 0.05 and $0.2 \mu \mathrm{g} \mathrm{g} \mathrm{g}^{-1}$ wet weight of sediment when $50 \mu \mathrm{l}$ of sample was injected. The mean recovery of OTC from the sediment was $57.5 \%$. The method is used in an experimental study of the kinetics of OTC in the sediment of tanks. These tanks were polluted by a seawater effluent coming from another tank into which OTC was added ( $45 \mathrm{~g} \mathrm{~d}^{-1}$ for $7 \mathrm{~d}$ ). During medication, OTC concentrations in the sediment gradually increased to peak at a mean value of $4.05 \mu \mathrm{g} \mathrm{g}^{-1}$. The average half-life of OTC in the sediment was $60.4 \mathrm{~d}$. Fourteen days after the end of medication, the OTC concentration in the sediment was still high (average $1.67 \mathrm{\mu g} \mathrm{g}^{-1}$ ). The results varied between tanks because of slight differences in temperature, light intensity and water flow between them. The results indicate that OTC may be very persistent in the sediment and that the disappearance of OTC is faster in sea-water than in sediment. It is suggested that the formation of complexes between OTC and some components of the sediment, such as divalent cations, might delay the release of OTC by sediment into sea-water It can be assumed that benthic organisms living in this sediment may be also contaminated by OTC.
\end{abstract}

\section{INTRODUCTION}

The development of fish farming in salt-marshes along the French Atlantic coastline is responsible for the pollution of sea water by oxytetracycline (OTC) (Pouliquen et al. 1993). It could also be responsible for the pollution of sediment by OTC or its degradation products. In fact, because of its wide antibacterial spectrum and high potency, OTC is commonly used in fish farming as an antibiotic against various diseases caused by Gram-negative and Gram-positive bacteria.

The drug, which is mixed in feed, is administered to fish at a dosage rate of 50 to $100 \mathrm{mg}$ per $\mathrm{kg}$ of biomass per day for 8 to $10 \mathrm{~d}$. Due to the reduced feeding of fish suffering from bacterial diseases and the low absorption of OTC through the intestinal tract of fish (Cravedi et al. 1987), a large part of the medicated feed presumably reaches the environment surrounding the fish farms.

Several methods using high-performance liquid chromatography (HPLC) for analysing OTC in plasma and fish tissue have been established (Onji et al. 1984,
Norlander et al. 1987, Björklund 1988, Murray et al. 1988, Rogstad et al. 1988, Einvindvik \& Rasmussen 1989, Iversen et al. 1989, Long et al. 1990). Only 3 analyses have been undertaken on sediment (Jacobsen \& Berglind 1988, Samuelsen 1989, Björklund et al. $1990,1991)$. The first aim of the present study was to develop a simple, rapid and accurate method for analysing OTC in sediment by HPLC. The second aim was to estimate the decomposition rate of OTC in sediment by carrying out an experiment on the sediment of tanks polluted by a seawater effluent. This effluent contained OTC and was released by another tank in which fish farm conditions were emulated

\section{MATERIAL AND METHODS}

Chemicals. Citric acid monohydrate $\left(\mathrm{C}_{6} \mathrm{H}_{8} \mathrm{O}_{7} \cdot \mathrm{H}_{2} \mathrm{O}\right)$, orthophosphoric acid $\left(\mathrm{H}_{3} \mathrm{PO}_{4} ; 85 \%\right)$ and ethylenediaminetetraacetic acid disodium salt dihydrate $\left(\mathrm{Na}_{2}\right.$ EDTA $\left.\cdot 2 \mathrm{H}_{2} \mathrm{O}\right)$ were supplied by Merck (Darmstadt, 
Germany). Perchloric acid $\left(\mathrm{HClO}_{4}\right)$ and disodium hydrogen phosphate dodecahydrate $\left(\mathrm{Na}_{2} \mathrm{HPO}_{4} \cdot 12 \mathrm{H}_{2} \mathrm{O}\right)$ were obtained from Prolabo (Paris, France). HPLCgrade acetonitrile was supplied by $\mathrm{BDH}$ Chemicals (Toronto, Canada). HPLC-grade methanol was obtained from Carlo-Erba (Milan, Italy). Oxytetracycline hydrochloride ( $91 \%$ purity) was obtained from Pfizer (Amboise, France). All reagents used were of analytical grade.

MaclIvaine buffer ( $\mathrm{pH}$ 3.0) consisted of $0.1 \mathrm{M}$ citric acid : 0.2 $\mathrm{M}$ disodium hydrogen phosphate (79.45:20.55 v/v). $0.1 \mathrm{M} \mathrm{Na}_{2}$ EDTA McIlvaine buffer ( $\mathrm{pH} 4.0$ ) was prepared by dissolving $37.224 \mathrm{~g}$ of $\mathrm{Na}_{2}$ EDTA $\left(2 \mathrm{H}_{2} \mathrm{O}\right)$ in water, adjusting $\mathrm{pH}$ to 4.0 with Macilvaine buffer (pH 3.0) and diluting to $1 \mathrm{l}$.

HPLC-apparatus. The chromatograph (Varian 5000; Varian, Palo Alto, CA, USA) was connected to an analytical column (LiChroSpher $100 \mathrm{RP}-18 \mathrm{E}_{\text {; }} 5$ um particle size, $125 \times 4 \mathrm{~mm}$; Merck) and a guard column (LiChroSpher 100 RP-18E; $5 \mu \mathrm{m}$ particle size, $4 \times 4 \mathrm{~mm}$; Merck). The UV detector was a Vari-Chrom UV 50 (Varian). Peak heights were calculated on a D-2500 integrator (Merck). The data were handled with a computer Deskpro 386/s Mod 403.5 (Compaq, Houston, TX, USA) equipped with the HPLC Manager Software System (Merck).

Chromatography. The chromatographic conditions were the same as described in Pouliquen \& Pinault (1992). The mobile phase used was a mixture of $240 \mathrm{ml}$ of acetonitrile and $760 \mathrm{ml}$ of $0.02 \mathrm{M}$ orthophosphoric acid solution, $\mathrm{pH} \mathrm{2.3.} \mathrm{The} \mathrm{mixture} \mathrm{was} \mathrm{filtered}$ with a Millipore HPLC solvent filtration system and Nalgene $47 \mathrm{~mm}, 0.20 \mu \mathrm{m}$ nylon filters, and then sonicated for $15 \mathrm{~min}$. The column was reconditioned for 2 $h$ after each day of operation with acetonitrile: water $(50: 50 \mathrm{v} / \mathrm{v})$ at a flow rate of $0.2 \mathrm{ml} \mathrm{min}^{-1}$. Detection was done at $355 \mathrm{~nm}$ at an operating flow rate of $1.2 \mathrm{ml}$ $\min ^{-1}$.

Experimental conditions and apparatus. The experiment took place at the IFREMER AQUALIVE Laboratory in Noirmoutier (France). A long, rectangular tank (a raceway of $10 \times 1 \times 1 \mathrm{~m}$ ) filled with seawater (salinity $33.1 \%$ ) was used in the experiment.

Four smaller tanks $(2 \times 2 \times 0.6 \mathrm{~m}), \mathrm{A}, \mathrm{B}, \mathrm{C}$ and $\mathrm{T}$, were also used; Tank $T$ was the control tank. An $8 \mathrm{~cm}$ sediment layer was added to all the tanks. Then, 3 commercial shellfish species commonly reared at the site (Crassostrea gigas, Ruditapes philippinarum and Scrobicularia plana) were placed in each tank, a total of 154 animals per tank*.

\footnotetext{
- OTC concentrations in the shellfish will be reported in a later publication
}

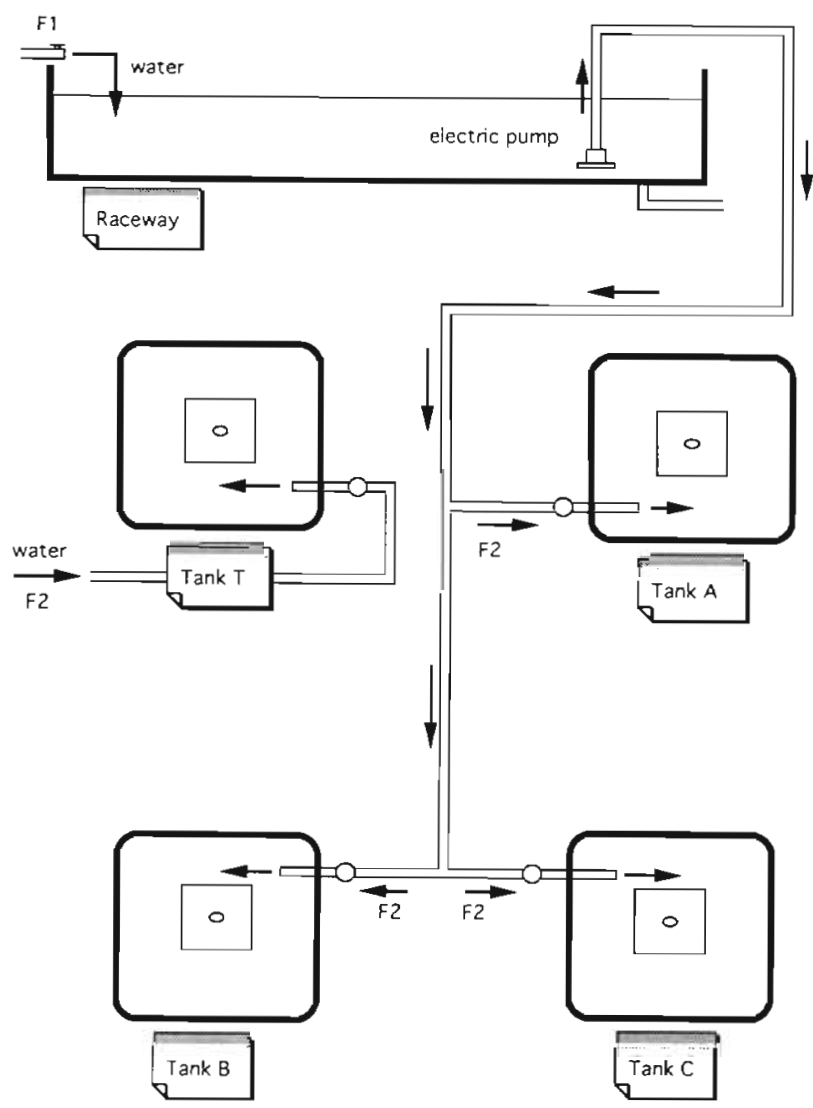

Fig. 1 Experimental apparatus and water circulation

The seawater flows, which induced a weak current, were $6.7 \mathrm{l} \mathrm{min}^{-1}(\mathrm{~F} 1)$ in the raceway and $2.2 \mathrm{I} \mathrm{min}^{-1}(\mathrm{~F} 2)$ in the 4 tanks (Fig. 1). The level of seawater in the raceway and tanks was changed each day to $128 \pm 10 \%$ and $182 \pm 10 \%$ (mean $\pm \mathrm{SD}$ ), respectively, in order to simulate the tides.

OTC was administered at a dosage rate of $200 \mathrm{mg}$ $\mathrm{kg}^{-1}$ fish $\mathrm{d}^{-1}$ for $7 \mathrm{~d}$ based on the theoretical assumption that there were $225 \mathrm{~kg}$ of fish in the raceway, OTC was used at a dosage rate above normal because that is the usual practice in this type of fish farming. Moreover, in the field, stocking levels are very different from one fish farm to another and are usually overestimated because of the turbid water in these farms. The experimental situation represented the worst possible conditions, inasmuch as the OTC was not absorbed by cultured organisms and effluents were raised to a maximum

The medicated feed containing OTC was prepared each morning and was distributed in the raceway at 09:00 and 17:00 h. The morning portion was immediately distributed in the raceway. The afternoon portion was protected from natural and artificial light until it was distributed. 
The experiment lasted for $21 \mathrm{~d}$, and was divided into 2 periods: a $7 \mathrm{~d}$ treatment period during which OTC was distributed in the raceway, and a $14 \mathrm{~d}$ posttreatment period.

During the $21 \mathrm{~d}$ of study, all experimental conditions were recorded. All tanks were illuminated by natural light, with the nights being of about $10 \mathrm{~h}$ duration. The average temperature, $\mathrm{pH}$ and salinitiy of the sea water were $14.5^{\circ} \mathrm{C}, 8.64$ and $33.1 \%$ respectively. The average concentration of calcium by wet weight of sediment was $67.8 \mathrm{mg} \mathrm{g}^{-1}$.

Sampling. Sampling was performed during the treatment and post-treatment periods. Sediment samples of about $15 \mathrm{~g}$ were taken from the 4 tanks, and put into polystyrene bottles. All the bottles were immediately stored in black bags and maintained at $-20^{\circ} \mathrm{C}$ until the analysis was carried out.

Sample preparation. Sample preparation was adapted from the method described by Samuelsen (1989). A $1 \mathrm{~g}$ sediment sample was transferred to a polypropylene tube $(5 \mathrm{ml})$ and extracted twice with 3 and $2 \mathrm{ml}$ of $0.1 \mathrm{M} \mathrm{Na} \mathrm{NaDTA}_{2}$ McIlvaine buffer ( $\mathrm{pH}$ 4.0). After centrifugation at $3500 \times g$ for $15 \mathrm{~min}$ at $4{ }^{\circ} \mathrm{C}$, the combined supernatants were filtered through an MC $25 \mathrm{~mm} 0.45 \mu \mathrm{m}$ Analypore. One milliliter of the filtrate was transferred to a polypropylene tube $(1.5 \mathrm{ml})$. After centrifugation at $11000 \times \mathrm{g}$ for $5 \mathrm{~min}$ at $4{ }^{\circ} \mathrm{C}, 50 \mu \mathrm{l}$ were injected into the HPLC column.

All the above steps were conducted in subdued light because of the instability of OTC in light. Each sample of sediment was prepared in duplicate, and each duplicate was injected twice; reported OTC concentration was the mean of the 4 determinations. HPLC chromatograms typical for sediment are shown in Fig. 2.

Standard curves. A concentrated stock solution of OTC was prepared in methanol $\left(1 \mathrm{mg} \mathrm{ml}^{-1}\right)$ and was stable for 1 mo when stored at $-20^{\circ} \mathrm{C}$. A diluted stock solution (100 $\left.\mathrm{ug} \mathrm{ml}^{-1}\right)$ was also prepared in methanol immediately before use. Aliquots of the diluted stock solution were further diluted with $0.1 \mathrm{M}$ perchloric acid in order to give working solutions that were protected from direct sun and artificial light throughout the analysis.

Preliminary HPLC experiments were carried out using working solutions containing OTC in the range 0.05 to $5 \mu \mathrm{g} \mathrm{m} \mathrm{m}^{-1}$ and sediment containing OTC in the range 0.05 to $5 \mu \mathrm{g} \mathrm{g}{ }^{-1}$.

At the beginning of each day of operation, a set of standard curves was prepared using sediment to which OTC was added in amounts corresponding to 0.4 and $1.6 \mu \mathrm{g} \mathrm{g}^{-1}$. The OTC concentrations in the sediment samples were calculated with reference to standard curves.
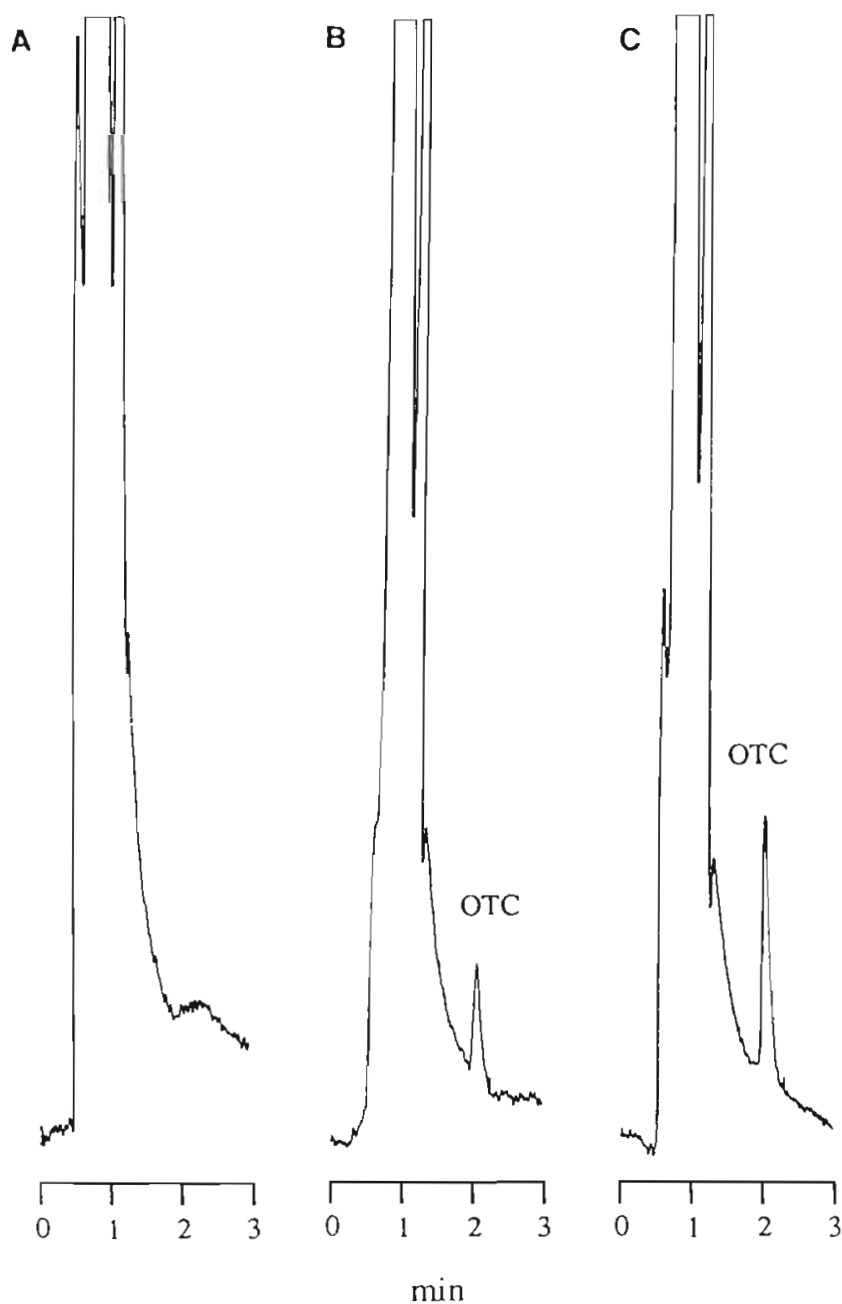

Fig. 2. HPLC chromatograms of sediment samples of experimental shellfish farms. (A) Control sample of sediment without antibiotic; (B) sample of sediment containing oxytetracycline at a concentration of $1.40 \mathrm{ug} \mathrm{g}^{-1}$; (C) sample of sediment containing oxytetracycline at a concentration of $4.40 \mu \mathrm{g} \mathrm{g}^{-1}$ Conditions: mobile phase, acetonitrile : $0.02 \mathrm{M}$ orthophosphoric acid solution, $\mathrm{pH} 2.3(24 \cdot 76 \mathrm{v} / \mathrm{v})$; column $125 \times 4 \mathrm{~mm}$,

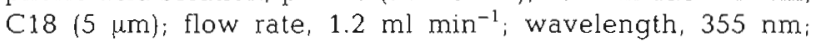
recorder sensitivity, 0.01 absorbance unit full scale; chărt speed, $1 \mathrm{~cm} \mathrm{~min}^{-1}$; injection volume, $50 \mu \mathrm{l}$

\section{RESULTS}

\section{Validation of the method for OTC determination}

The OTC was eluted in $2.1 \mathrm{~min}$ and no changes in retention time were noted with continual column use.

Regression analysis of the data obtained by running a series of OTC solutions in sediment for 5 consecutive days showed the response to be linear in the range examined $(y=b x+a$ where $x$ represents peak height in $\mu V$ and $y$ the OTC concentration in $\mu \mathrm{g} \mathrm{g}^{-1}$ ). The slope and correlation coefficient were $0.0020 \pm 0.0001$ and $0.992 \pm 0.004$, respectively (mean $\pm \mathrm{SD}$ ). 
The limit of detection was $0.05 \mu^{-1} \mathrm{~g}^{-1}$, and the limit of determination was $0.2 \mu \mathrm{g} \mathrm{g}^{-1}$ (precision $\pm 10 \%$ ).

The within-day precision of the method was tested by a single analyst spiking sediment at 5 concentrations of OTC and analysing 10 replicates during the same day. The between-day precision was tested by 2 analysts spiking sediment at an OTC concentration of $0.8 \mu \mathrm{g} \mathrm{g}^{-1}$ and analysing 10 replicates for 2 consecutive days. The relative standard deviations of within- and between-day precision were $5.15 \pm 0.25 \%$ and $2.65 \pm 0.04 \%$ respectively (mean \pm SD)

The accuracy of the method was studied by spiking sediment at 5 OTC concentrations $(0.2,0.4,0.8,1.6$, $3.2 \mu \mathrm{g} \mathrm{g}^{-1}$ ) and analysing 2 replicates. The average recovery of OTC from the sediment was $57.5 \%$ (relative standard deviation $4.53 \%$ ).

A study of stability showed that there was no significant decrease in the amount of OTC in sediment stored at $-20{ }^{\circ} \mathrm{C}$ for $6 \mathrm{wk}$.

\section{Experimental study}

The OTC concentrations in the sediment of Tanks A, $B$ and $C$ are shown in Fig. 3. The drug levels in the sediment of Tank $\mathrm{T}$ were always below the limit of detection of the HPLC assay. Those in the sediment of Tanks $\mathrm{A}, \mathrm{B}$ and $\mathrm{C}$ were below this limit only during the first day of the OTC treatment. No metabolites of OTC in the form of extra peaks on HPLC chromatograms could be seen in the sediment.

During the $7 \mathrm{~d}$ of the antibiotic treatment, the OTC concentration increased and reached a maximum on Day 7 at 19:00 h. The maximum levels of OTC in the sediment were between 3.47 and $4.91 \mu \mathrm{g} \mathrm{g}^{-1}$.

During the $14 \mathrm{~d}$ after the antibiotic treatment, the OTC concentration in the sediment slowly decreased. At 19:00 h on Day 21, the levels of OTC were between 1.50 and $1.96 \mu \mathrm{g} \mathrm{g}^{-1}$.

The average values of OTC concentration in seawater and sediment of Tanks A, B and C during the $14 \mathrm{~d}$ after antibiotic treatment are shown in Fig. 4.

Disappearance of OTC from sediment was well described by a monocompartmental kinetic model. The plot of $\log$ (ppm OTC) versus time was used to determine the half-life $\left(\mathrm{T}_{1 / 2}\right)$ of OTC in sediment (Table 1 ). The average $T_{1 / 2}$ of OTC in sediment was $60.4 \mathrm{~d}$.

\section{DISCUSSION}

\section{Validation of the method for OTC determination}

Analytical validation showed the method of OTC determination to have good specificity, linearity, sen-
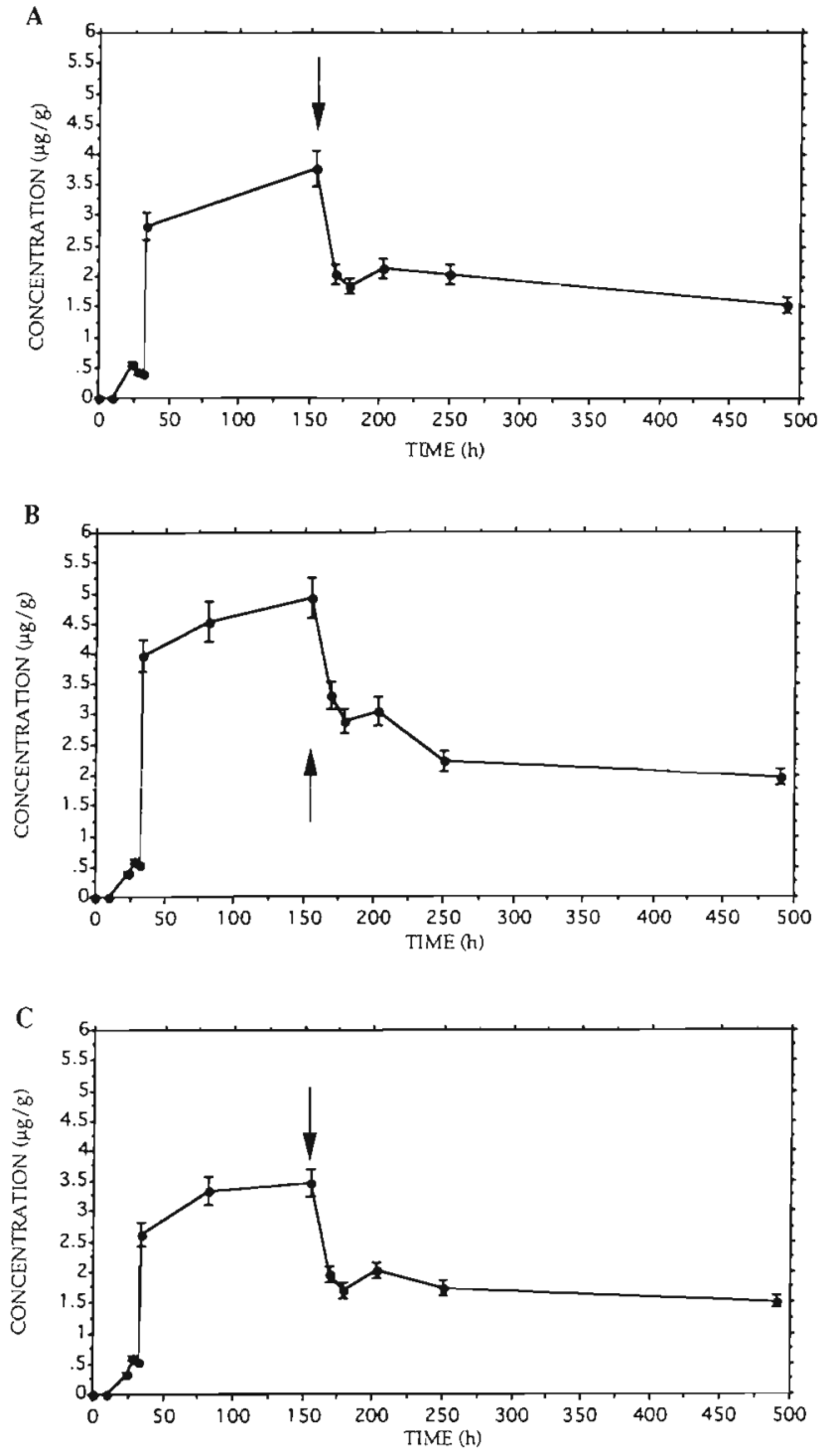

Fig. 3. Oxytetracycline concentrations in sediment samples from Tank A (A), Tank B (B) and Tank C (C). Each point is a mean value of 4 concentrations. Bars represent standard error of mean $(5 \%)$. Arrows indicate the end of medication

sitivity, precision and accuracy. As the clean-up procedure involved only filtration and centrifugation, the method was simple, rapid and inexpensive. The detection limit for the methods of Samuelsen (1989) and Björklund et al. (1990) was $0.01 \mu \mathrm{g} \mathrm{g}^{-1}$ when injecting 150 and $20 \mu$ l of sample respectively. Their methods were also linear in the range examined $(0.2$ to $25 \mu \mathrm{g} \mathrm{g}^{-1}$ ).

Recovery of OTC from sediment was constant from one concentration to another, so an internal standard was not used. The average recovery of OTC from the sediment was low (57.5\%). Samuelsen (1989) and Björklund et al. (1990) found mean recoveries of 98.4 
Fig. 4. Oxytetracycline concentrations in sediment and seawater samples from Tanks $A, B$ and $C$ after the last day of medication. Each point is a mean value of the concentrations calculated for each of the 3 tanks

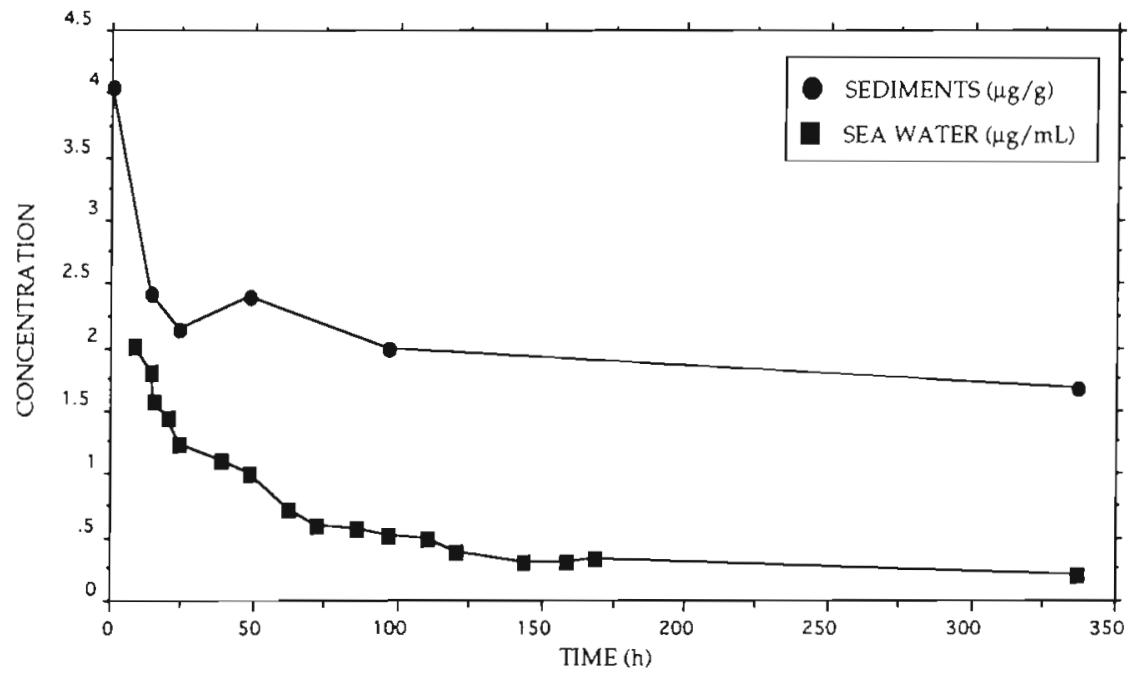

and $88.6 \%$ respectively. The low recovery obtained in the present study could be explained either by the degradation of OTC by the bacterial flora in the sediment, or by the formation of complexes between the drug and some components of the sediment, such as divalent cations. If they are stable, these bound complexes could have had hydrophilic properties which were different from those of free OTC. Thus, they could not be detected by the extraction and HPLC method developed for free OTC (Björklund et al. 1991).

The mobile phase used gave high peak responses and did not result in baseline drift or tailing.

\section{Experimental study}

As indicated, during the $7 \mathrm{~d}$ of medication, the OTC concentration in the sediment gradually increased to peak on Day 7 at 19:00 h. During the same period, the OTC concentration in the seawater increased to reach a peak about 2 h after each administration of the medicated feed, and then decreased (Pouliquen et al. 1993). This indicated that OTC accumulated in the sediment and not in the seawater. Samuelsen (1989) also showed the degradation of OTC to be faster in seawater than in sediment. It is well known that tetracyclines are degraded in water solutions by photodecomposition

Table 1 Half-lives $\left(T_{1,2}\right)$ of oxytetracycline in the sediment of Tanks A, B and C

\begin{tabular}{|cc|}
\hline Tank & $T_{1,2}(\mathrm{~d})$ \\
\hline A & 75.2 \\
B & 41.0 \\
C & 83.2 \\
\hline
\end{tabular}

and that their half-lives depend on temperature, light intensity and $\mathrm{pH}$ (Oka et al. 1989). In sediments, OTC is protected from light and currents. Moreover, OTC in sediment might form complexes with cations, such as $\mathrm{Ca}^{2+}, \mathrm{Mg}^{2+}, \mathrm{Fe}^{2+}, \mathrm{Fe}^{3+}$ or $\mathrm{Al}^{3+}$, delaying the release of OTC by sediment into seawater

After the last distribution of medicated feed, the OTC concentration in the sediment decreased quickly between 19:00 h on Day 7 and 09:00 h on Day 8 and then slowly until 19:00 h on Day 21. The end of medication was quickly followed by a decrease in OTC concentration

The decline in drug residues in the sediment could be explained by diffusion and washing away from the top layers of the sediment due to water currents. This decline could also be explained by degradation, especially by bacteria present in the sediment. However, no extra peaks indicating metabolites were found in HPLC chromatograms. Therefore, because OTC is easily soluble in seawater, the solvation and diffusion processes were most likely the major mechanisms leading to OTC escape from the sediment (Samuelsen 1989). No report regarding degradation processes of OTC in the sediment has yet been published. Thus, it cannot be determined from our experimental study which part of the OTC was degraded in the sediment and which disappeared by diffusion.

The slow decline in OTC concentration in the sediment is shown in Fig. 3. Indeed, the OTC concentration in sediment, $14 \mathrm{~d}$ after the end of the treatment, was still high (average $1.67 \mu \mathrm{g} \mathrm{g}^{-1}$ ). This persistence of OTC in the sediment could be explained, as described above, by the possibility of the drug-forming complexes with some cations.

The average half-life of the OTC disappearance in Tanks A, B and C was 60.4 d. Therefore, OTC formed persistent residues in sediment as described by previous 
studies. Jacobsen \& Berglind (1988) reported a half-life of $10 \mathrm{wk}$ for OTC in sediment from fish farms, Samuelsen (1989) 32 to $64 \mathrm{~d}$ and Björklund et al. (1990) $419 \mathrm{~d}$

The half-lives of OTC in sediment were different among Tanks A, B and C: 75.2, 41.0 and $83.2 \mathrm{~d}$, respectively. These results can be explained by the slight differences in temperature, light intensity and flow from one tank to another. The half-lives of OTC in seawater were also different among the 3 tanks (Pouliquen et al. 1993).

The decline in OTC concentration in seawater and sediment from Tanks A, B and C is shown in Fig. 4. It is interesting to note that the curves of OTC kinetics in both seawater and sediment are parallel. These results indicate that disappearance of OTC was faster in seawater than in sediment, as described previously (Samuelsen 1989), and that the decline in OTC residues in sediment was minimal.

In conclusion, it can be stated that OTC persists at relatively high concentrations in the sediment for $14 \mathrm{~d}$ after medication. These results indicate that shellfish living on the sediment (Crassostrea gigas) or in the sediment (Scrobicularia plana and Ruditapes philippinarum) are exposed to significant OTC concentrations for a significant period of time. As a consequence, their marketability could be affected by these residues.

Given the fact that the major part of the OTC administered to diseased fish reaches the environment, this comprehensive study may be applied to a prediction of the impact of OTC on marine environments situated close to fish farms located in salt-marshes.

Acknowledgements. We thank Mr Pascal Sanders (CNEVALMV, Javené, France) for his help in discussions on the kinetic results, Mr Jean-Marc Debernardi for collecting the samples of sediment, Ms Michaëlle Larhantec for her technical assistance and Prof. Sandra Woehrle for re-reading this manuscript. This study was supported by a grant from the Regional Council of Pays de la Loire and the General Councils of Loire Atlantique and Vendée and was conducted with experimental facilities of the IFREMER AQUALIVE Laboratory (Noirmoutier, France).

\section{LITERATURE CITED}

Bjorklund, H. (1988). Determination of oxytetracycline in fish by high-performance liquid chromatography. $J$. Chromatogr. 432: 381-387

This article was submitted to the editor
Björklund, H., Bondestam, J., Bylund, G. (1990). Residues of oxytetracycline in wild fish and sediments from fish farms. Aquaculture 86: 359-367

Björklund, H., Rabergh, C. M. I., Bylund, G. (1991). Residues of oxolinic acid and oxytetracycline in fish and sediments from fish farms. Aquaculture 97: 85-96

Cravedi, J. P., Choubert, G., Delous, G. (1987). Digestibility of chloramphenicol, oxolinic acid and oxytetracycline in rainbow trout and influence of these antibiotics on lipid digestibility. Aquaculture 60: 133-141

Einvindvik, K., Rasmussen, K. E. (1989). Determination of oxytetracycline in fish plasma by high-performance liquid chromatography and column-switching. J. Liq. Chromatogr. 12: 3061-3071

Iversen, B., Aanesrud, A., Kolstad, A. K. (1989). Determination of oxytetracycline in plasma from rainbow trout using high-performance liquid chromatography with ultraviolet detection. J. Chromatogr. 493: 217-221

Jacobsen, P. and Berglind, L. (1988). Persistence of oxytetracycline in sediments from fish farms. Aquaculture 70 : $365-370$

Long, A. R., Hsieh, L. S., Malbrough, M. S., Short, C. R., Barker, S. A. (1990). Matrix solid phase dispersion isolation and liquid chromatographic determination of oxytetracycline in catfish (Ictalurus punctatus) muscle tissue. J. Assoc. Off. Anal. Chem. 73: 864-867

Murray, J., MacGill, A., Hardy, R. (1988). Development of a method for the determination of oxytetracycline in trout. Food Addit. Contam. 5: 77-83

Nordlander, I., Johnsson, H., Osterdahl, B. (1987). Oxytetracycline residues in rainbow trout analysed by a rapid HPLC method. Food Addit. Contam. 4: 291- 296

Oka, H., Ikai, Y., Kawamura, N., Yamada, M., Harada, K. I., Ito, S. Suzuki M. (1989). Photodecomposition products of tetracycline in aqueous solution. J. Agric. Food Chem. 37: 226-231

Onji, Y., Uno, M., Tanigawa, K. (1984). Liquid chromatographic determination of tetracycline residues in meat and fish. J. Assoc. Off. Anal. Chem. 64: 1135-1137

Pouliquen, H., Le Bries, H., Pinault, L. (1993). Experimental study on the decontamination kinetics of seawater polluted by oxytetracycline contained in effluents released from a fish-farm located in a salt-marsh. Aquaculture (in press)

Pouliquen, H., Pinault, L. (1992). Méthode de dosage de l'oxytétracycline dans l'eau de mer par chromatographie liquide haute pression. Ann. Falsif. Expert. chim. toxicol. 85: $111-120$

Rogstad, A., Hormazabal, V., Yndestad, M. (1988). Optimization of solid phase extraction of oxytetracycline from fish tissue and its determination by HPLC. J. Chromatogr. 11: $2337-2347$

Samuelsen, O. B. (1989). Degradation of oxytetracycline in seawater at two different temperatures and light intensities and the persistence of oxytetracycline in the sediment from a fish farm. Aquaculture 83: 7-16

Manuscript first received: April 21, 1992

Revised version accepted: September 21, 1992 